\title{
The link between separation and political party preference: Selectivity or causal influence?
}

\author{
Marieke Voorpostel, FORS, Switzerland (marieke.voorpostel@fors.unil.ch) \\ Hilde Coffé, University of Bath, UK (․․R.Coffe@bath.ac.uk) \\ Ursina Kuhn, FORS, Switzerland (ursina.kuhn@fors.unil.ch)
}

The Version of Record of this manuscript has been published and is available in Journal of Elections, Public Opinion and Parties, 19.11.2018, https://www.tandfonline.com/doi/full/10.1080/17457289.2018.154577

This paper studies the impact of separation from marital and cohabiting relationships on political party preferences. Relying on longitudinal data (19992017) from the Swiss Household Panel, it examines to what extent differences in party preferences between partnered and separated individuals are the result of a selection effect (with individuals who separate having different party preferences prior to their separation compared with partnered individuals) or of a causal effect (with individuals changing their party preferences following separation). The analyses show that partnered individuals are significantly more likely to support a party with Christian values (the CVP) compared with separated individuals, and indicate that this is due to a selection effect. For populist right (SVP) voting, we find a causal effect of separation. Interestingly, the event of separation increases the likelihood of supporting the populist right SVP. While separated individuals are more likely to support the social democratic party (PSS) than married individuals, we do not find a significant selection or causal effect of separation on support for the PSS. Overall, our results confirm the relevance of taking a dynamic approach distinguishing selection and causal effects and reveal that while the effect of separation on voters' party choice is modest but significant.

Keywords: separation, divorce, political party preference, panel data analysis, multiparty system, Switzerland

\section{Introduction}

Family life has changed dramatically among all Western post-industrialized societies 
during the last few decades. The decline in marital stability and increase of separation ${ }^{1}$ has been among the most important of these changes. Hence, it is not surprising that the effect of separation has been widely studied in the social sciences, showing that separation has a profound impact on people's lives, including their socioeconomic position, social networks, and political participation and interest (e.g. Kalmijn and Broese van Groenou 2005; Stoker and Jennings 1995; Duncan and Hoffman 1985; Voorpostel and Coffé 2012). Little is, however, known about the effect of separation on political party choice. Given the increasing levels of separation around the globe, understanding this link and the political salience of separation is crucial. If separation is found to affect party choice, it may also help us to understand the growing volatility in electoral outcomes and choices.

Since separation is known to influence various characteristics which impact people's party choice, such as their socioeconomic position, it seems fair to assume that separation will affect party choice. In addition, previous research has revealed that being married influences people's party preference (Coffé and Need 2010; Lampard 1997; Stoker and Jennings 2005; Kingston and Finkel 1987). If marriage changes people's party preference, ending a marriage is also likely to have an effect. Most of the limited existing research does indeed suggest that separation has an impact on people's party preferences (e.g. Edlund et al. 2005; Chapman 1985; Edlund and Pande 2002; Fahs 2007; Kingston and Finkel 1987; Plutzer and McBurnett 1991; Smith 2007; Wilson and Lusztig 2004; but see Kern 2010).

1 We use the term separation in reference to both the dissolution of a marriage and a cohabitating relationship, and the term separated in reference to people whose marriage or cohabitating relationship has ended. 
Our study aims to add to the literature on the link between separation and party choice using data from the Swiss Household Panel (SHP) (1999-2017). In contrast to the cross-sectional data used in most existing research (Edlund et al. (2005), Edlund and Pande (2002) and Kern (2010) being notable exceptions), the SHP data gives us the opportunity to investigate changes in people's relationship status in a dynamic way. This allows us to investigate not only how political party preferences of partnered ${ }^{2}$ and separated individuals differ, but also enables us to assess whether, and to what extent, this difference is due to the actual event of separation, or whether people who will experience separation already have a different party preference prior to their separation compared with individuals who will not experience a separation. Moreover, the Swiss context allows us to investigate the effect of separation in a multiparty context.

Before moving to the introduction of our data and analyses, the next section presents relevant theories on the effect of separation on party choice and how this can be explained, thereby focusing on two explanations: a selection effect and a causal effect.

\section{Theoretical background}

\section{Separation and party choice}

Divorce rates across the developed world have steadily increased over recent decades (Amato 2010; Coleman 2013; González and Viitanen 2009; Kennedy and Ruggles 2014). Indeed, the commonly quoted statistic that around half of marriages in the US end in divorce appears to be not far from the truth (Amato 2010). Divorce rates in

2 We use the term partnered in reference to people who are married or in cohabitating relationships. 
Europe have also been steadily climbing, with many countries having divorce rates in the 30 to 40 percent range (Coleman 2013). The experience of separation has the potential to produce profound changes in people's lives, including relocation (often to less favourable housing), a general deterioration of living standards, and, more often for women, re-entering the labour market while also facing childrearing duties as a lone parent (Amato 2010, Struffolino, Bernardi and Voorpostel 2016). These new circumstances may well be accompanied by changing views on society as well as on the role of the government in providing welfare or childcare arrangements. As a result, political party preference may change. Given the high and increasing divorce rates, it is important to understand these possible changes in party preference. If separation does indeed affect citizens' voting behaviour, it could significantly affect electoral outcomes given the frequency that separation occurs in society.

Studies that have focussed on the relationship between separation and party choice have indeed found that there is a link between separation and party choice. Generally, those who are separated are more likely to vote for left-wing parties (see however Finseraas, Jakobsson and Kotsadam 2012; Kern 2010). For example, using British and American data respectively, studies by Chapman (1985) and Kingston and Finkel (1987) (see also Fahs 2007 looking at female graduates of Michigan) demonstrate that divorced individuals are more likely to vote left-wing, and to have more leftist political attitudes and policy preferences than married people, who tend to be more likely to vote right-wing (Plutzer and McBurnett 1991). Using data from the 1972-2006 General Social Surveys, Smith (2007) shows how family structure is associated with political participation and voting behaviour, with the married leaning to the right and most non-married groups to the left. Also, he demonstrates how the political role of family structure has increased over time. These findings have been 
replicated in Canada, where Wilson and Lusztig (2004) used election study data to show that married people are more likely than the unmarried to lean towards the right politically. The majority of studies on the relationship between separation and vote choice hypothesise - but typically do not empirically test - that there is a causal link through changes in the economic status of those who experience separation (Kern 2010).

The main limitation of most of the studies discussed so far is that they are based on cross-sectional data, and do not actually observe individuals going through a separation. Therefore, they cannot draw definite conclusions about whether separation caused a change in party preferences or whether the group of separated individuals already held different preferences prior to their separation. Only a handful of existing studies do use panel data. Edlund et al. (2005) and Edlund and Pande (2002) use a longitudinal design for data in Europe and the US respectively and conclude that separation does cause individuals - particularly women - to lean more to the left. These studies do, however, not systematically theorize and empirically investigate a possible distinction between selection and causality. Kern (2010), in his turn, does not exploit the longitudinal structure to estimate the effect of separation by following individuals experiencing the event while in the panel but rather compares divorced with continuously married (and widowed) individuals. He does not find an effect of separation.

The current study solves the shortcomings of previous research and explores two possible explanations for the link between separation and party choice: a selection effect and a causal effect. In the following two sub-sections, we examine literature relating to separation and political behaviour, and propose hypotheses to test the extent to which 
the link between separation and vote choice can be explained by a selection or causal effect.

\section{A Selection Effect}

People who will eventually separate may have a different party preference prior to this event, given that characteristics known to be related to party choice are also known to affect the likelihood of experiencing a separation. The risk of divorce is lower for couples who both hold on to the traditional, gender-specialized division of labour, especially if the wife holds more traditional gender values (Hohmann-Marriott 2006; Kalmijn, De Graaf and Poortman 2004). Gender egalitarian attitudes are known to increase the likelihood of supporting left-wing, liberal parties (Inglehart and Norris 2003).

Furthermore, religious couples are less likely to divorce, probably due to the pro-family outlook of most religions (de Graaf and Kalmijn 2006; Lehrer 2004). Religious individuals are also more likely to support religious or conservative parties (van der Brug, Hobolt and de Vreese 2009). Those who will eventually separate may thus already be less likely to support a religious party prior to their separation than couples who stay continuously partnered.

Overall, given that characteristics such as religion, and family and gender values are related to both the likelihood of experiencing a separation and party choice, we expect to find a selection effect with individuals who will separate having a different party preference prior to their separation compared with continuously partnered individuals. Our first hypothesis thus reads:

Hypothesis 1: Separated individuals are less likely to support parties with traditional family values and a religious background prior to their 
separation compared with individuals who will not experience a separation.

The selection effect may, however, differ between women and men as some research has shown a different effect of religiosity and gender values on the likelihood to separate between women and men. For example, research has revealed that women with traditional views on gender and division of labour are less likely to separate whereas egalitarian women may be more likely to consider or anticipate divorce (e.g. Greenstein 1995; Lueptow, Guss and Hyden 1989). By contrast, men with egalitarian attitudes have been found to be less likely to separate than men with traditional attitudes (e.g. Blair 1993; Kaufman 2000). Given the link between traditional gender attitudes and supporting parties with traditional family values, the expectation that separated individuals will be less likely to support parties with traditional family values will particularly hold among women. There is also some evidence suggesting that the negative effect of religion on separation is stronger among women than men (Brown, Orbuch and Bauermeister 2008). Therefore, it is in particular separated women who may be less likely to support parties with a religious background prior to their separation. Hence, we also propose the following variation of Hypothesis 1:

Hypothesis 1a: Hypothesis 1 is expected to be stronger among women compared with men.

\section{A Causal Effect}

There are various factors that may cause the experience of separation to have an effect on party preference. First, it is known that married partners tend to vote for the same party, partly because they influence one another (Coffé and Need 2010; Lampard 1997; Stoker and Jennings 2005, Kuhn 2009 and 2016 for Switzerland). This influence 
generally ends when a relationship finishes, and people's party preference may consequently change. Relationship dissolution also leads to changes in a person's social network (Wrzus et al. 2013), and the loss of some connections and the addition of new ones may also lead to a change in political preferences (Zuckerman 2005). This argumentation, however, does not help to explain in which direction a party preference will change following separation.

Second, and most commonly suggested as an explanation for a link between separation and left-wing voting, the dissolution of a partnership, be it from marriage or unmarried cohabitation, is a life event that often comes with far reaching consequences, including negative effects on people's socio-economic status and financial resources (Amato 2010; Avellar and Smock 2005; Vaus et al 2017). As voters' socio-economic status is known to have a major impact on policy attitudes and party preferences (e.g., Brooks et al. 2006; Lipset 1981; Evans 2000) and is a driver behind changes in party preference (Sanders and Brynin, 1999), such a change in socio-economic status after partnership dissolution is anticipated to affect party choice. There is indeed evidence that a change in people's financial situation affects their party preference (Kuhn 2016), and there is broad agreement that the economic impact of separation is an important pathway contributing to a change in voting behaviour following separation (Arunachalam and Watson 2015; Edlund and Pande 2002). Because of the experience of a decrease in their socio-economic position, separated individuals may become more likely to support policies around social welfare benefits and thus left-wing parties that tend to focus on such policies (Gerson 1987; Rehm 2009). Our hypothesis thus reads as follows:

Hypothesis 2: The experience of a separation increases the likelihood of supporting economically left-wing parties. 
However, there are also gender differences in the economic consequences of separation, with men generally suffering fewer negative economic consequences (Bröckel and Andreß 2015; Leopold 2018; Vaus et al 2017) and women facing more often challenges related to raising children as a lone parent (Bernardi \& Mortelmans 2018). This may also explain some of the gender differences in the political alignment of voters after separation: as men do better economically following separation, they tend to vote more to the right, whereas women - who suffer negative economic consequences - tend to vote more to the left. Relying on data from the German Socioeconomic Panel (GSOEP), Edlund, Haider and Pande (2005) conclude that divorce results in a move towards the left, but only among women. This confirmed an earlier American study by Edlund and Pande (2002) which indicated a significant gender differential effect of divorce on political preference and that, following divorce, women are more likely to support the Democratic Party (see however Finseraas, Jakobsson and Kotsadam 2012 who do find that women are more likely to lean towards the left but find no evidence that it can be explained by women's risk of divorce measured as relationship quality). Therefore, a further specification of Hypothesis 2 is:

Hypothesis 2a: Hypothesis 2 is expected to be stronger among women compared with men.

In addition to a change in socio-economic position and a related shift in needs and expectations from the government, a person's changed circumstances following separation may also alter family-related and gender role values. Within marriage, traditional gender role patterns and conservative family values are still relatively common (Baxter et al. 2008; Ryser \& Le Goff 2015; Plissner 1983), although cohabiting couples tend to have a more egalitarian gender ideology (Davis et al. 2007). The event of separation has been related to (changes in) more egalitarian attitudes and 
less conservative attitudes towards family. For example, Thornton and Freedman (1979) concluded that exposure to divorce is related to a shift towards more egalitarian attitudes. Thornton (1985) found that people who experienced a divorce subsequently held more positive attitudes towards marital dissolution. In sum then, our hypothesis is: Hypothesis 3: The experience of a separation decreases the likelihood of supporting parties with traditional family values.

\section{Data, measures and method}

\section{Data}

To answer our research question and investigate the link between separation and party choice, we analyze data from the SHP. The SHP is an ongoing yearly panel study that started in 1999 with 5,074 households (including 7,799 household members) that have been randomly selected and followed over time. Refreshment samples were added in 2004 (2,538 households and 3,645 individuals) and 2013 (3,989 households and 6,090 individuals). An additional sample for households living in the canton of Vaud was added in 2013 (935 households and 1,253 individuals). In 2017 the original sample still contained 2,657 households (4,232 individuals), the second sample still included 1,241 households (1,836 individuals), the third sample comprised 2,178 households $(3,411$ individuals). These retention rates are comparable to those obtained in other large-scale household panels. As the interviews were conducted by telephone, item nonresponse is negligible. For the current study, we use all data from 1999 to 2017 (waves 1 to 19). 
From the overall sample, we selected couples who have been together at least one year and who are Swiss citizens. ${ }^{3}$ A substantial proportion of these couples remained partnered throughout the observation period. These 11,916 continuously partnered respondents contributed 76,576 observations.

There are 1,284 respondents who experienced separation in the panel. This group consists of those who were living with a partner at some point in the study, but who stopped living together and reported not having a partner for at least one wave, yielding 5,485 observations before separation and 5,632 observations after separation. Since the data contains gaps in which respondents skipped one or more waves, the actual moment of separation may not exactly coincide with the first time we observed a separation in the data; it may have taken place earlier. In order to exclude influences of a new partner on party preferences, separated individuals were censored from the moment they re-partnered. ${ }^{4}$ The duration of separation ranges between 1 and 17 years with an average of 3.6 years. All observations before partnering are dropped from the sample. In short, our sample includes partnered individuals and separated individuals who do not live with a new partner.

\section{Measures}

\section{Dependent Variable}

Our dependent variable, party choice, is based on the (open) question asking which

3 We exclude the non-Swiss population since they have no right to vote. The data contain 56 individuals in same-sex relationships. These are included in the analyses. Excluding them gives similar results as those presented below.

4 Similarly, partnered individuals who transitioned to widowhood or whose partner moved to an institution were censored after the event. 
party respondents would vote for if elections for the National Council were held tomorrow. We focus on vote intention for the four largest Swiss political parties, which are also the parties forming the consensual Swiss federal government: the Social Democratic Party (PSS), the Swiss Christian-Democratic People's Party (CVP), FDP The Liberals (FDP and former liberal party) and the Swiss People's Party (SVP). The PSS (economic left, liberal family values) acknowledges increased family diversity, supports measures to decrease gender inequality, and favours a strong welfare state with more financial support for public childcare. In the election for the national council in 2015, which were the most recent elections organized during the time period investigated in the current study, the PSS attained a vote share of 18.9 percent. There are two parties on the centre-right: FDP and CVP. The FDP (which attained 16.4 percent of the vote in 2015) favours limited state intervention and has a liberal view in terms of family values (economic right, liberal family values). The CVP (economic right, traditional family values) has its roots in Catholicism and holds a traditional family view that values the institution of marriage, but it also is in favour of state interventions that facilitate paid work for mothers and caring for children for fathers, such as public childcare places and flexible workhours. Christianity is invoked as the basis for solidarity. It attained 11.6 percent of the vote in 2015 . Finally, the SVP (economic right, traditional family values) is a populist right-wing party that shares CVP's traditional family values regarding marriage, but, unlike the CVP, also strongly promotes a traditional division of labour. It has evolved from a conservative agrarian party to a radical right and increasingly authoritarian party (McGann and Kitschelt 2005). Christianity is pictured by the SVP as the cultural heritage that needs to be protected from other influences, notably Islam. The SVP strongly opposes immigration and European integration, contrary to the centre-right and left parties. Although the SVP 
is the largest party (with a vote share of 29.4 percent in 2015) and part of the Swiss consensual federal government, it presents itself and is perceived as an opposition party rather than as a part of the political establishment. Table 1 gives an overview of the parties' positions on the economic left-right scale and with regard to family values.

Table 1. Position Swiss parties on the economy and family issues

\begin{tabular}{lll}
\hline & $\begin{array}{l}\text { Traditional family } \\
\text { values }\end{array}$ & Liberal family values \\
\hline Economic left & & PSS \\
Economic right & CVP/SVP & FDP \\
\hline
\end{tabular}

The voting intention of the respondents included in our analytical sample in 2015 were comparable to the outcomes of the 2015 national elections for the FDP (16.3 percent), whereas respondents who support the PSS were overrepresented (26.5 percent) and those who support the CVP and the SVP were underrepresented (8.3 percent and 21.7 percent respectively).

Of the couples where both partners indicated a vote intention for a specific party (19 parties in total), 61 percent named the same party. The likelihood to support the same party increases with duration of the relationship, from 47.9 percent in the first year to 63.9 percent for those having the same partner over 20 years.

To measure vote intention, we constructed a dummy variable for each of the four parties with 1 referring to intending to vote for that particular party and 0 referring to not intending to vote for that particular party. The latter category also includes observations where a respondent did not prefer any party (including "don't know", "would not vote" and "would vote for a candidate, not a party", "no party"

5 In the election of the Swiss national council, citizens can vote for as many candidates as there are seats available in their canton (between 1 and 36). Candidates of all party lists can be combined. 
focus is on party choice, we also ran our analyses with a dichotomous dependent variable, coded 0 when respondents gave any party preference or reported that they would vote for a candidate and not a party, and 1 if the response was “don't know”, "would not vote" or "no party." As such, we assess to what extent separation is linked to having a party preference or not.

\section{Explanatory Variable}

Our central explanatory variable is the experience of separation. This variable is coded as a dummy variable, taking the value of 0 in all periods in which respondents are living with a partner, and 1 in all periods after separation and in which respondents indicated not having a partner. This means that all observations from the continuously partnered group are coded 0 , and that the group of respondents who experience separation has 0 's before the separation and 1's after the event (until they have a new partner, at which point they are dropped from the analysis). This modelling strategy supposes that the treatment effect is constant over time. ${ }^{6}$

\section{Control Variables}

In our logistic regression analyses explaining party choice (Figure 1, and Table 3), we control for some basic socio-demographic characteristics to make the separating group comparable with the continuously partnered group. In particular, we control for gender (female, male (ref.)), age, education (lower than secondary (ref.), general upper secondary, apprenticeship, vocational tertiary, academic tertiary level), own children

6 The number of observations in the separation group was unfortunately too small to have enough power for more detailed ways of modelling separation, such as years since separation. 
younger than 18 living in the household (yes, no), employment status (employed, inactive/unemployed (ref.)), and duration of the relationship in years (for separated individuals, the duration refers to the length of their previous relationship). To account for the higher attrition rate of separated individuals we also included the number of waves the respondent was interviewed. Finally, we include dummy variables for survey years to account for each period. Table 2 shows the descriptive statistics of all variables included in this study. We do not control for variables which we argue may explain why those who separate have a different party preference prior to separation such as religiosity (de Graaf and Kalmijn 2006; Lehrer 2004) given that they may explain away the effect of separation. ${ }^{7}$

Table 2. Descriptive statistics

\begin{tabular}{lccccc}
\hline Variable & Obs & Mean & Std.Dev. & Min & Max \\
\hline SVP & 86,971 & 0.123 & 0.329 & 0 & 1 \\
PSS & 86,971 & 0.186 & 0.389 & 0 & 1 \\
CVP & 86,971 & 0.0810 & 0.273 & 0 & 1 \\
FDP & 86,971 & 0.118 & 0.322 & 0 & 1 \\
No party & 86,971 & 0.176 & 0.380 & 0 & 1 \\
Separated & 87,693 & 1.128 & 0.490 & 1 & 3 \\
Female & 87,693 & 0.541 & 0.498 & 0 & 1 \\
Age (cont.) & 87,693 & 51.27 & 14.18 & 18 & 97 \\
Education: Lower than sec. & 87,471 & 0.106 & 0.308 & 0 & 1 \\
Education: General upper sec. & 87,471 & 0.0965 & 0.295 & 0 & 1 \\
Education: Apprenticeship & 87,471 & 0.431 & 0.495 & 0 & 1 \\
Education: Vocational tertiary & 87,471 & 0.189 & 0.391 & 0 & 1 \\
Education: Academic tertiary & 87,471 & 0.177 & 0.382 & 0 & 1 \\
Own children younger than 18 in & & & & & \\
household & 87,693 & 0.366 & 0.482 & 0 & 1 \\
Employed & 87,689 & 0.711 & 0.454 & 0 & 1 \\
Duration of partnership (cont.) & 85,264 & 21.90 & 11.28 & 0 & 35 \\
\hline
\end{tabular}

Note: Cont. indicates that it is a continuous variable.

7 When we include religiosity in the analyses explaining selection effects, we find that the negative effect of separation on the likelihood to vote CVP becomes weaker. 


\section{Method}

Our analyses aim to investigate the link between separation and party choice and examine to what extent this may be the result of selection or causality. To do so, we present three analyses below. In the first analysis, we assess overall differences between partnered and separated individuals, by pooling all panel waves and estimating for the different dependent variables (party preferences) logistic regression models. We cluster standard errors within persons to account for the nested structure of the data (observations within individuals). To examine the overall difference between partnered and separated individuals, we compare all observations in which respondents reported to be partnered with all observations in which individuals are separated. This approach gives an overall picture of differences between partnered and separated individuals and is similar to the approach commonly used in cross-sectional studies. All control variables presented above are included in this analysis.

In the second analysis, we investigate to what extent any differences in party preference between partnered and separated individuals may be due to selection into separation. To test whether individuals who separate already have different preferences prior to separation compared with continuously partnered individuals (as suggested in Hypothesis 1), we again estimate logistic regression models with clustered standard errors within persons. This time, we compare observations from respondents who will stay with their partner in the SHP with observations from partnered individuals who will separate at a later wave in the panel (but we only include the observations from when they are partnered and thus exclude observations after their separation). With this design, any differences in party preferences between the groups indicate a selection effect: individuals who separate hold different party preferences already prior to separation. All control variables presented above are included in the models. 
The third and final analysis focuses on the causal effect of separation on vote intention (as suggested in Hypothesis 2 and Hypothesis 3) by looking at changes in party preference over time. To do this, we apply a fixed effects approach, which compares the difference in vote intentions before and after separation within individuals (among those who separate). The continuously partnered group are included in the analysis to separate the effect of aging from the effect of separation. We only include age as a control variable in this analysis, as there is little variation over time in the other control variables. ${ }^{8}$ In contrast to cross-sectional regression, selection into separation will not bias coefficients in fixed effects regression models as long as the selection is due to time-invariant effects or observed effects. ${ }^{9}$

For the analyses examining selection and causal effects of separation, we also estimate a model that includes an interaction between gender and separation allowing us to test Hypothesis 1a and Hypothesis 2a.

8 We did run analyses including the control variables presented above. The results of these analyses were the same as the results for the analyses presented below (Table 4).

9 Although conditional logistic models would also be suitable because they fit the binary dependent variable, their drawback is that they only include persons who show variation on the dependent variable, thus those whose party preference changes between waves. This would imply a drastic reduction of the sample size. Another difficulty of the conditional logistic models is that the size of the regression coefficients cannot be interpreted and it is not possible to compute predicted probabilities. As a sensitivity check, we estimated all models both with logistic and linear regression to ensure that the linearity assumption does not influence conclusions. The main results were similar in both models. 


\section{Results}

\section{Cross Sectional Analysis: Comparison between Partnered and Separated}

\section{Individuals}

In a first analysis, we estimate logistic regressions including all control variables presented above and comparing the overall difference in party preferences between partnered and separated individuals (tables not shown). Figure 1 presents the predicted probabilities for separated and partnered individuals based on these models as average marginal effects.

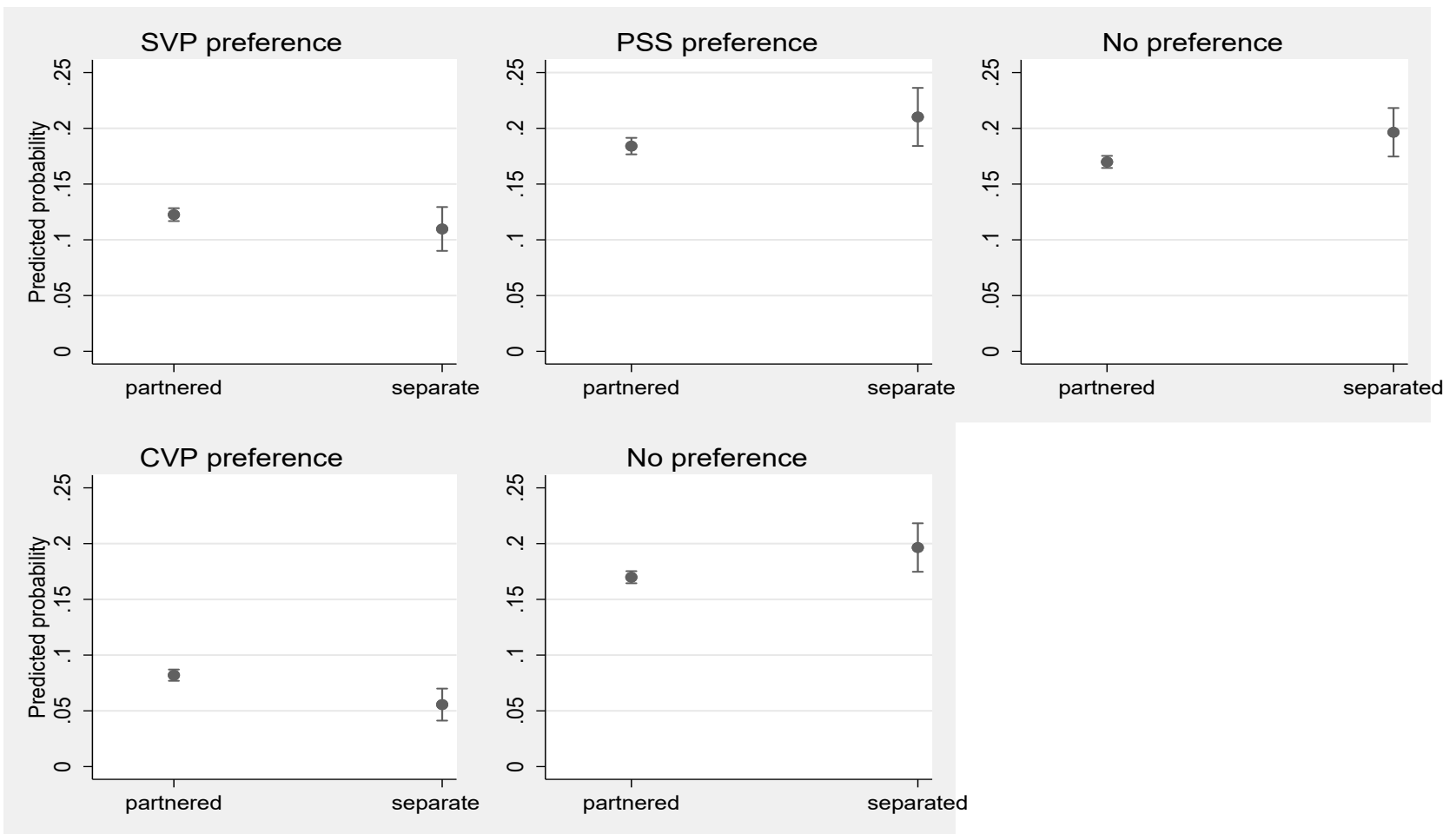

Figure 1. Predicted Probabilities Comparing Partnered and Separated Individuals

Figure 1 reveals that separated individuals are slightly more likely to prefer the PSS (probability of 21 percent) compared with partnered individuals (probability of 18 percent, $\mathrm{p}=.04$ ). This finding is in line with findings from existing studies showing that divorce is related to left-wing preferences (Chapman, 1985; Kingston \& Finkel, 1987; 
Edlund et al., 2005; Edlund \& Pande, 2002). We also find that separated individuals are somewhat less likely to prefer the Christian-Democratic CVP; a party with traditional family values (probability of 6 percent) compared with partnered individuals (probability of 8 percent, $\mathrm{p}=.003$ ). Yet, partnered and separated individuals do not have significantly different preferences for the SVP; a party which also focuses on traditional family values. There is no difference between partnered and separated individuals for the FDP either. Finally, separated individuals are more likely to report no political preference (for a party or a candidate) compared with partnered individuals (probability of 20 percent among partnered individuals and probability of 17 percent among separated individuals, $\mathrm{p}=.01)$.

\section{Logistic Regression Models Examining Selection}

In the second part of our analysis, we assess to what extent the differences in party preference between continuously partnered and formerly partnered individuals results from selection. In other words, we examine whether the group who eventually separated already had different party preferences, compared with the continuously partnered group, before experiencing separation in logistic regression models. We include the same control variables as in the previous models. To take into account the likelihood of an anticipation effect of separation, we omitted the observation from the wave prior to separation in these models. ${ }^{10}$ The results are presented in predicted probabilities (Table 3 and Figure 2) and show for each party the likelihood of preferring that particular party for the separation group (before separation) and the continuously partnered group.

10 This observation was not included since the effects of separation may already start to show in anticipation of the event of separation when the individual is still partnered. 
Table 3. Logistic regression analyses explaining party preferences comparing partnered individuals who will eventually separate prior to their separation and continuously partnered individuals

\begin{tabular}{|c|c|c|c|c|c|c|c|c|c|c|}
\hline & $\begin{array}{l}\text { SVP } \\
\mathrm{b} \text { (tstat) }\end{array}$ & $\begin{array}{l}\text { SVP } \\
b \text { (tstat) }\end{array}$ & $\begin{array}{l}\text { PSS } \\
\mathrm{b}(\mathrm{se})\end{array}$ & $\begin{array}{c}\text { PSS } \\
\text { b (tstat) }\end{array}$ & $\begin{array}{l}\text { CVP } \\
\mathrm{b} \text { (tstat) }\end{array}$ & $\begin{array}{c}\text { CVP } \\
\mathrm{b} \text { (tstat) }\end{array}$ & $\begin{array}{c}\text { FDP } \\
b \text { (tstat) }\end{array}$ & $\begin{array}{c}\text { FDP } \\
\text { b (tstat) }\end{array}$ & $\begin{array}{c}\text { No } \\
\text { preference } \\
\text { b (tstat) }\end{array}$ & $\begin{array}{c}\text { No } \\
\text { preference } \\
\text { b (tstat) }\end{array}$ \\
\hline $\begin{array}{l}\text { Pre-separation } \\
\text { (ref. remaining partnered) }\end{array}$ & $\begin{array}{l}-0.198 \\
(-1.64)\end{array}$ & $\begin{array}{l}-0.228 \\
(-1.31)\end{array}$ & $\begin{array}{l}0.099 \\
(1.08)\end{array}$ & $\begin{array}{l}0.046 \\
(0.32)\end{array}$ & $\begin{array}{c}-0.420^{* *} \\
(-3.12)\end{array}$ & $\begin{array}{l}-0.273 \\
(-1.32)\end{array}$ & $\begin{array}{l}0.021 \\
(0.18)\end{array}$ & $\begin{array}{l}0.093 \\
(0.52)\end{array}$ & $\begin{array}{l}0.131 \\
(1.69)\end{array}$ & $\begin{array}{l}0.218 \\
(1.73)\end{array}$ \\
\hline Female & $\begin{array}{c}-0.553 * * \\
(-9.17)\end{array}$ & $\begin{array}{c}-0.555^{* *} \\
(-8.97)\end{array}$ & $\begin{array}{l}0.051 \\
(0.89)\end{array}$ & $\begin{array}{l}0.046 \\
(0.77)\end{array}$ & $\begin{array}{l}-0.096 \\
(-1.29)\end{array}$ & $\begin{array}{l}-0.086 \\
(-1.13)\end{array}$ & $\begin{array}{c}-0.283 * * \\
(-4.86)\end{array}$ & $\begin{array}{c}-0.276 * * \\
(-4.61)\end{array}$ & $\begin{array}{l}0.559 * * \\
(12.06)\end{array}$ & $\begin{array}{l}0.567^{* *} \\
(11.81)\end{array}$ \\
\hline Pre-separation* female & & $\begin{array}{l}0.059 \\
(0.25)\end{array}$ & & $\begin{array}{l}0.085 \\
(0.47)\end{array}$ & & $\begin{array}{l}-0.258 \\
(-0.98)\end{array}$ & & $\begin{array}{l}-0.136 \\
(-0.59)\end{array}$ & & $\begin{array}{l}-0.125 \\
(-0.80)\end{array}$ \\
\hline Age & $\begin{array}{l}-0.000 \\
(-0.14)\end{array}$ & $\begin{array}{l}-0.000 \\
(-0.14)\end{array}$ & $\begin{array}{l}0.002 \\
(0.77)\end{array}$ & $\begin{array}{l}0.002 \\
(0.77)\end{array}$ & $\begin{array}{l}-0.000 \\
(-0.09)\end{array}$ & $\begin{array}{l}-0.000 \\
(-0.08)\end{array}$ & $\begin{array}{c}0.011^{* *} \\
(3.48)\end{array}$ & $\begin{array}{c}0.011 * * \\
(3.49)\end{array}$ & $\begin{array}{c}-0.019 * * \\
(-7.68)\end{array}$ & $\begin{array}{c}-0.019 * * \\
(-7.67)\end{array}$ \\
\hline \multicolumn{11}{|l|}{$\begin{array}{l}\text { Education (ref. lower than } \\
\text { sec.) }\end{array}$} \\
\hline General upper secondary & $\begin{array}{c}-1.083 * * \\
(-7.68)\end{array}$ & $\begin{array}{c}-1.083^{* *} \\
(-7.69)\end{array}$ & $\begin{array}{c}0.971 * * \\
(8.32)\end{array}$ & $\begin{array}{c}0.971 * * \\
(8.31)\end{array}$ & $\begin{array}{l}-0.151 \\
(-0.96)\end{array}$ & $\begin{array}{l}-0.151 \\
(-0.96)\end{array}$ & $\begin{array}{c}0.564 * * \\
(4.26)\end{array}$ & $\begin{array}{c}0.564 * * \\
(4.26)\end{array}$ & $\begin{array}{l}-1.125 * * \\
(-12.21)\end{array}$ & $\begin{array}{c}-1.125^{* *} \\
(-12.21)\end{array}$ \\
\hline Apprenticeship & $\begin{array}{c}-0.256^{* *} \\
(-3.05)\end{array}$ & $\begin{array}{c}-0.256^{* *} \\
(-3.06)\end{array}$ & $\begin{array}{c}0.290^{* *} \\
(2.87)\end{array}$ & $\begin{array}{c}0.290^{* *} \\
(2.87)\end{array}$ & $\begin{array}{l}0.051 \\
(0.41)\end{array}$ & $\begin{array}{l}0.052 \\
(0.42)\end{array}$ & $\begin{array}{c}0.483 * * \\
(4.72)\end{array}$ & $\begin{array}{c}0.484 * * \\
(4.73)\end{array}$ & $\begin{array}{c}-0.378 * * \\
(-5.95)\end{array}$ & $\begin{array}{c}-0.378 * * \\
(-5.94)\end{array}$ \\
\hline Vocational tertiary & $\begin{array}{c}-0.567 * * \\
(-5.55)\end{array}$ & $\begin{array}{c}-0.567 * * \\
(-5.56)\end{array}$ & $\begin{array}{c}0.471^{* *} \\
(4.12)\end{array}$ & $\begin{array}{c}0.470^{* *} \\
(4.11)\end{array}$ & $\begin{array}{l}0.093 \\
(0.67)\end{array}$ & $\begin{array}{l}0.095 \\
(0.68)\end{array}$ & $\begin{array}{c}0.876^{* * *} \\
(7.81)\end{array}$ & $\begin{array}{c}0.877 * * \\
(7.82)\end{array}$ & $\begin{array}{c}-0.987 * * \\
(-12.46)\end{array}$ & $\begin{array}{c}-0.986^{* *} \\
(-12.45)\end{array}$ \\
\hline Academic tertiary & $\begin{array}{c}-1.995^{* *} \\
(-15.85)\end{array}$ & $\begin{array}{c}-1.995 * * \\
(-15.85)\end{array}$ & $\begin{array}{c}1.006^{* *} \\
(9.20)\end{array}$ & $\begin{array}{c}1.005^{* *} \\
(9.19)\end{array}$ & $\begin{array}{l}0.003 \\
(0.02)\end{array}$ & $\begin{array}{l}0.005 \\
(0.03)\end{array}$ & $\begin{array}{c}0.937^{* *} \\
(8.29)\end{array}$ & $\begin{array}{c}0.938^{* *} \\
(8.29)\end{array}$ & $\begin{array}{c}-1.456^{* *} \\
(-17.61)\end{array}$ & $\begin{array}{c}-1.455^{* *} \\
(-17.60)\end{array}$ \\
\hline $\begin{array}{l}\text { Own children younger than } 18 \\
\text { in household }\end{array}$ & $\begin{array}{c}-0.164 * * \\
(-2.97)\end{array}$ & $\begin{array}{c}-0.164 * * \\
(-2.97)\end{array}$ & $\begin{array}{l}-0.081 \\
(-1.76)\end{array}$ & $\begin{array}{l}-0.081 \\
(-1.76)\end{array}$ & $\begin{array}{c}0.391 * * \\
(6.31)\end{array}$ & $\begin{array}{c}0.391 * * \\
(6.32)\end{array}$ & $\begin{array}{l}-0.062 \\
(-1.13)\end{array}$ & $\begin{array}{l}-0.062 \\
(-1.13)\end{array}$ & $\begin{array}{l}0.011 \\
(0.27)\end{array}$ & $\begin{array}{l}0.011 \\
(0.28)\end{array}$ \\
\hline Employed & 0.103 & 0.103 & -0.005 & -0.004 & -0.054 & -0.054 & 0.008 & 0.008 & $-0.180 * *$ & $-0.180 * *$ \\
\hline
\end{tabular}




\begin{tabular}{|c|c|c|c|c|c|c|c|c|c|c|}
\hline & $(1.73)$ & $(1.73)$ & $(-0.09)$ & $(-0.08)$ & $(-0.82)$ & $(-0.82)$ & $(0.15)$ & $(0.14)$ & $(-4.35)$ & $(-4.35)$ \\
\hline Duration of relationship & $\begin{array}{l}-0.005 \\
(-1.47)\end{array}$ & $\begin{array}{l}-0.005 \\
(-1.48)\end{array}$ & $\begin{array}{l}-0.002 \\
(-0.68)\end{array}$ & $\begin{array}{l}-0.002 \\
(-0.69)\end{array}$ & $\begin{array}{c}0.015^{* *} \\
(3.20)\end{array}$ & $\begin{array}{c}0.015^{* *} \\
(3.20)\end{array}$ & $\begin{array}{l}0.006 \\
(1.65)\end{array}$ & $\begin{array}{l}0.006 \\
(1.65)\end{array}$ & $\begin{array}{c}-0.014 * * \\
(-5.07)\end{array}$ & $\begin{array}{c}-0.014^{* *} \\
(-5.06)\end{array}$ \\
\hline Number of observations & $\begin{array}{c}-0.021 * * \\
(-4.16)\end{array}$ & $\begin{array}{c}-0.021 * * \\
(-4.16)\end{array}$ & $\begin{array}{c}0.025 * * \\
(5.77)\end{array}$ & $\begin{array}{c}0.025^{* *} \\
(5.77)\end{array}$ & $\begin{array}{l}0.009 \\
(1.53)\end{array}$ & $\begin{array}{l}0.009 \\
(1.53)\end{array}$ & $\begin{array}{c}-0.013 * * \\
(-2.92)\end{array}$ & $\begin{array}{c}-0.013 * * \\
(-2.92)\end{array}$ & $\begin{array}{c}-0.032 * * \\
(-8.63)\end{array}$ & $\begin{array}{c}-0.032 * * \\
(-8.63)\end{array}$ \\
\hline Constant & $\begin{array}{c}-0.890^{* *} \\
(-5.18)\end{array}$ & $\begin{array}{c}-0.889 * * \\
(-5.16)\end{array}$ & $\begin{array}{c}- \\
2.131 * * \\
(-12.81)\end{array}$ & $\begin{array}{c}- \\
2.127 * * \\
(-12.74)\end{array}$ & $\begin{array}{c}-2.960 * * \\
(-12.76)\end{array}$ & $\begin{array}{c}- \\
2.968 * * \\
(-12.77)\end{array}$ & $\begin{array}{c}-2.933^{* *} \\
(-15.85)\end{array}$ & $\begin{array}{c}-2.937 * * \\
(-15.83)\end{array}$ & $\begin{array}{c}0.397 * * \\
(3.00)\end{array}$ & $\begin{array}{c}0.390 * * \\
(2.95)\end{array}$ \\
\hline Observations & 79,563 & 79,563 & 79,563 & 79,563 & 79,563 & 79,563 & 79,563 & 79,563 & 79,563 & 79,563 \\
\hline Pseudo R squared & 0.053 & 0.053 & 0.024 & 0.024 & 0.010 & 0.010 & 0.024 & 0.024 & 0.071 & 0.071 \\
\hline
\end{tabular}

$* \mathrm{p}<0.05 ; * * \mathrm{p}<0.01 ; * * * \mathrm{p}<0.001$ 

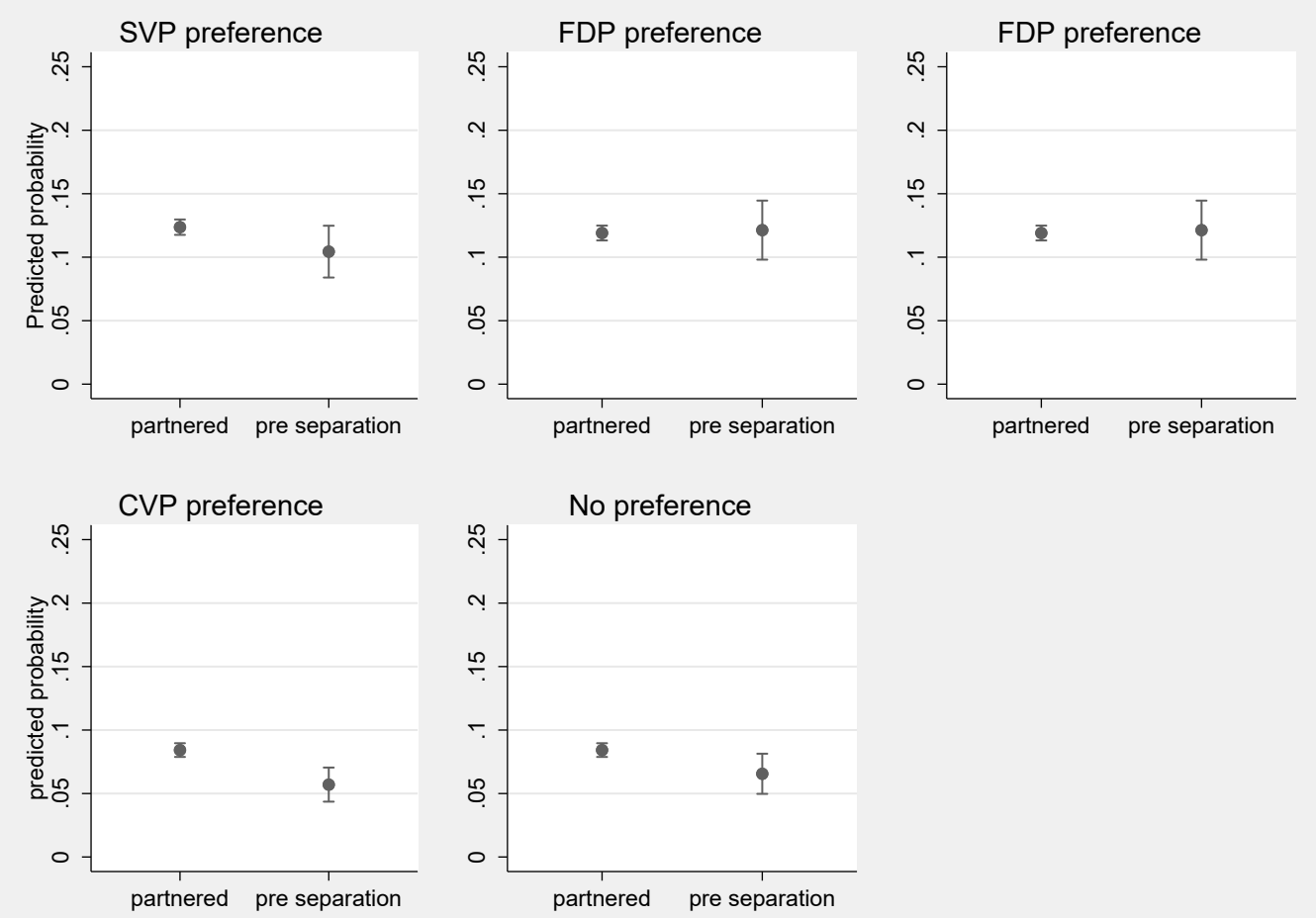

Note: Predicted Probabilities are based on the analyses presented in Table 3.

Figure 2. Predicted probabilities Comparing Continuously Partnered Individuals ("partnered") and Individuals Who Will Experience Separation Prior to Their Separation ("pre-separation")

Table 3 indicates that individuals who will eventually separate are significantly less likely to vote CVP before they separated (probability of 6 percent) compared with the continuously partnered group (probability of 8 percent, $p=0.002$ ). This confirms Hypothesis 1 which expected separated individuals to have less support for parties with traditional family values already prior to their separation. The likelihood of supporting PSS, SVP or FDP is similar between both groups. Additionally, there is no selection effect for having a party preference (compared with having no party preference). We 
find no support for Hypothesis 1a which stated that selection effects may differ for men and women as none of the interactions with gender are significant (see Table 3). ${ }^{11}$

\section{Fixed Effects Models Examining the Causal Effect of Separation}

In the third part of our analysis, we look at the causal effect of experiencing separation and investigate to what extent changes in political party preference occur following the event of separation on the individual level. In order words, we examine to what extent there is a causal effect of separation on party choice. To do so, we estimate individual fixed effects models controlling for age and period effects to take changes in preferences over time and as people age into account, irrespective of life cycle events. The results are presented in Table 4.

11 We also empirically explored interactions between separation and marital status (cohabitation or marriage), religious participation, income, relationship duration, education and parenthood (own children younger than 18 living in the household). These analyses showed significant interactions only for the CVP; parents, married individuals and those with apprenticeship or academic tertiary level education who separate are significantly less likely to support the CVP prior to separation compared with those who remain partnered. 
Table 4. Fixed effects models of political party preference, estimating within-person change in the separation group and controlling for changes in preferences in the continuously partnered control group

\begin{tabular}{|c|c|c|c|c|c|c|c|c|c|c|}
\hline & $\begin{array}{c}\text { SVP } \\
\text { b (tstat) }\end{array}$ & $\begin{array}{c}\text { SVP } \\
\text { b (tstat) }\end{array}$ & $\begin{array}{c}\text { PSS } \\
\mathrm{b} \text { (tstat) }\end{array}$ & $\begin{array}{c}\text { PSS } \\
\mathrm{b} \text { (tstat) }\end{array}$ & $\begin{array}{c}\text { FDP } \\
\text { b (tstat) }\end{array}$ & $\begin{array}{c}\text { FDP } \\
\mathrm{b} \text { (tstat) }\end{array}$ & $\begin{array}{c}\text { CVP } \\
\text { b (tstat) }\end{array}$ & $\begin{array}{c}\text { CVP } \\
\text { b (tstat) }\end{array}$ & $\begin{array}{c}\text { No } \\
\text { preference } \\
\mathrm{b} \text { (tstat) }\end{array}$ & $\begin{array}{c}\text { No } \\
\text { preference } \\
\text { b (tstat) }\end{array}$ \\
\hline Separated & $\begin{array}{l}0.011^{*} \\
(2.21)\end{array}$ & $\begin{array}{l}-0.000 \\
(-0.05)\end{array}$ & $\begin{array}{l}-0.008 \\
(-1.40)\end{array}$ & $\begin{array}{c}-0.002 * \\
(-0.21)\end{array}$ & $\begin{array}{l}-0.007 \\
(1.37)\end{array}$ & $\begin{array}{l}-0.005 \\
(-0.64)\end{array}$ & $\begin{array}{l}-0.005 \\
(-1.20)\end{array}$ & $\begin{array}{l}-0.013 \\
(-1.88)\end{array}$ & $\begin{array}{c}0.013^{*} \\
(2.01)\end{array}$ & $\begin{array}{l}0.014 \\
(1.36)\end{array}$ \\
\hline Separated*female & & $\begin{array}{l}0.017 \\
(1.80)\end{array}$ & & $\begin{array}{l}-0.009 \\
(-0.84)\end{array}$ & & $\begin{array}{l}-0.003 \\
(-0.26)\end{array}$ & & $\begin{array}{l}0.012 \\
(1.45)\end{array}$ & & $\begin{array}{l}-0.002 \\
(0.15)\end{array}$ \\
\hline Age & $\begin{array}{c}.002^{* * *} \\
(10.26)\end{array}$ & $\begin{array}{l}.002^{* * *} \\
(10.23)\end{array}$ & $\begin{array}{c}-.003 * * * \\
(-16.22)\end{array}$ & $\begin{array}{c}-.003^{* * *} \\
(-16.20)\end{array}$ & $\begin{array}{c}.001^{* * *} \\
(6.92)\end{array}$ & $\begin{array}{c}.001^{* * *} \\
(6.92)\end{array}$ & $\begin{array}{c}.001 * * * \\
(5.44)\end{array}$ & $\begin{array}{c}.001^{* * *} \\
(5.42)\end{array}$ & $\begin{array}{c}-.001^{* * *} \\
(-3.72)\end{array}$ & $\begin{array}{c}-.001 * * * \\
(3.72)\end{array}$ \\
\hline Constant & $\begin{array}{l}0.030 \\
(3.32)\end{array}$ & $\begin{array}{l}0.030 \\
(3.34)\end{array}$ & $\begin{array}{c}0.353 \\
(34.60)\end{array}$ & $\begin{array}{c}0.352^{* * *} \\
(34.58)\end{array}$ & $\begin{array}{c}0.052^{* * *} \\
(5.54)\end{array}$ & $\begin{array}{c}0.052^{* * *} \\
(5.53)\end{array}$ & $\begin{array}{c}0.039 * * * \\
(4.93)\end{array}$ & $\begin{array}{c}0.039 * * * \\
(4.95)\end{array}$ & $\begin{array}{c}0.220^{* * *} \\
(18.16)\end{array}$ & $\begin{array}{c}0.220^{* * *} \\
(18.16)\end{array}$ \\
\hline
\end{tabular}

$* \mathrm{p}<0.05, * * \mathrm{p}<0.01, * * * \mathrm{p}<0.001 \mathrm{n}=86,971$ from 13,159 individuals 
While we expected to find a positive causal effect of separation on the likelihood of supporting a left-wing party and a negative causal effect for parties with traditional family values (Hypotheses 2 and 3), Table 4 indicates that separation only affects a preference for SVP. In contrast to our hypotheses, however, following separation, the likelihood of preferring the SVP increases by 1 percentage point (or an odds ratio of 1.29 in the conditional logit model). Separation also increases the likelihood of not stating any party preference by 1.3 percentage points, suggesting that the experience of separation has a modest demobilizing effect.

When testing whether the hypothesized increased support for left-wing parties is found especially among women (Hypothesis 2a) we find no significant interaction effect with gender for any of the parties, nor for having no party preference. ${ }^{12}$

\section{CONCLUSION}

12 We also empirically explored interactions between separation and marital status (cohabitation or marriage), religious participation, income, relationship duration, education and parenthood (own children younger than 18 living in the household). These analyses revealed that some of the effects of separation are conditional upon these sociodemographic characteristics of individuals. Parents who separate are more likely to support the SVP and less likely to support the CVP following separation compared with individuals without children under 18 in the household. Married individuals who separate increase support for the SVP and decrease support for the FDP more strongly compared with cohabitors who separate. Separation increases support for the SVP only among the lower educated and lower income groups. Support for the CVP and FDP increases more strongly following separation for individuals with tertiary education (for the FDP also for general upper secondary education) compared with lower than secondary educated individuals. Separation has a stronger negative effect on the likelihood of supporting PSS among individuals who attend religious services compared with those who do not. The likelihood to not express a party preference increases especially following separation from marriage and from longer lasting relationships. 
Separation is known to have a major impact on people's lives (e.g. Voorpostel \& Coffé 2012; Kalmijn and Broese van Groenou 2005; Stoker and Jennings 1995; Duncan and Hoffman 1985). Little is known, however, about the effect of separation on party choice. Yet, given the increasing levels of separation, it is crucial to understand the impact of separation on people's party preference. Better understanding the ways in which life events, such as separation, affect political party preferences will also advance our insight into the increasing volatility in voting behaviour. Most of the limited available research indicates a "marriage gap" in voting, with married people being more conservative and right-wing compared with divorced or unmarried individuals (e.g. Plutzer and McBurnett 1991; Plissner 1983; Weisberg 1987). This scholarship has typically treated marital status as a static individual characteristic and looked at twoparty systems (see however Kern 2010). By contrast, and relying on longitudinal household panel data, we looked at partnership status in a dynamic way. Such a dynamic approach allowed us to disentangle selection into separation from the causal effect of separation on a change in party preference.

Our analyses, using data from the SHP (1996-2017), found that separated individuals were overall somewhat more likely to support the left-wing PSS and less likely to support the Christian CVP, which is in line with previous findings based on cross-sectional models. These differences in party preference, however, partly pre-date the event of separation: individuals who will separate at a later point in time are less likely to prefer a political party with traditional family, the Christian CVP, compared with continuously partnered individuals. This supports the idea that part of the differences in party preferences between partnered and separated individuals stems from different party preferences prior to the event of separation, rather than being an effect of separation itself. The fact that characteristics known to be related to party choice, such 
as religiosity and traditional family values (Inglehart and Norris 2003), are also known to affect the likelihood of experiencing a divorce (Cooke 2006; De Graaf and Kalmijn 2006; Haller and Hoellinger 1994; Kalmijn and Poortman 2006) may explain this.

Our study does, however, also find a modest causal effect of separation on people's preference for the populist right-wing SVP increasing following separation. This causal effect of separation holds particularly among women. This finding goes against our expectations of a decreased likelihood of supporting a party with traditional family values and right-wing parties following separation. One possible explanation is that SVP-voters may be offset by the traditional views on family before separation but may be attracted by their populist character after separation. In particular, the SVP's protectionist discourse of independence from the European Union and limiting immigration may be attractive to those who have seen their financial situation worsen, as often is the case following partnership dissolution. This discourse tends to take the foreground and outshines the stance of the SVP on family values in the public debate. Future research could usefully explore possible explanations for this finding in greater detail.

Although not the main focus of our study, our analyses also suggest a demobilising effect of separation. This lower likelihood of having any political party preference among separated individuals is due to a causal effect of separation. Individuals who separate are less likely to have a clear party preference after separation than when they lived with their partner. We also find that disengagement is somewhat more pronounced among women compared with men. This is in line with prior studies demonstrating a relationship between divorce and disengagement from politics (Coffé and Bolzendahl 2010; Voorpostel and Coffé 2012). 
The cross-sectional analyses revealed a positive effect of separation on supporting the PSS. The small size of the effect and the limited number of individuals in the SHP who experienced separation, prevented us, however, from assessing whether the cross-sectional differences between partnered and separated individuals in their preference for this party was due to selection or whether there was a causal effect of separation. The low number of separations also prevented us from investigating whether and how the effect of separation changes over time since we had to assume that the effect of separation was stable over time. As is found for other outcomes, such as life satisfaction and health (Anusic et al. 2014), it is, however, likely that the effect of separation is temporary. This is a promising avenue for future research on the link between separation and party preference.

Notwithstanding these limitations, distinguishing selection from causality is the best way to assess the impact of life events such as separation, and adds to our understanding of the implications of an experience like separation on individuals' political preferences. While our analyses showed that the impact of separation is relatively modest in the Swiss context, it is nonetheless important. As only one of the many factors shaping political party preference, we argue that even a small effect translates into a substantial number of voters in Switzerland who change their party preference based on the occurrence of a "private" event in the life course. Changes in family composition and marital and cohabitating relationship status, including increasing levels of separation, are apparent in Switzerland and most other postindustrialized societies. Taking the effect of separation into account improves our understanding of (changes in) electoral behaviour and outcomes. Investigating this event, as well as other life course events such as the transition to parenthood or home ownership, may improve our understanding of volatility in party preferences. 


\section{References}

Amato, P. R. (2010). Research on divorce: Continuing trends and new developments. Journal of Marriage and Family, 72(3), 650-666.

Anusic, I., Yap, S. Y., \& Lucas, R. (2014). Testing Set-Point Theory in a Swiss National Sample: Reaction and Adaptation to Major Life Events. Social Indicators Research, 119(3), 1265-1288.

Arunachalam, R., \& Watson, S. (2015). Divorce and the Political Gender Gap. Working paper, The Ohio State University.

Avellar, S., \& Smock, P. J. (2005). The Economic Consequences of the Dissolution of Cohabiting Unions. Journal of Marriage and Family, 67(2), 315-327.

Baxter, J., Hewitt, B., \& Haynes, M. (2008). Life Course Rransitions and Housework: Marriage, Parenthood, and Time on Housework. Journal of Marriage and Family, 70, 259-272.

Blair, S.L. (1993). Employment, Family, and Perceptions of Marital Quality Among Husbands and Wives. Journal of Family Issues. 14, 189-212.

Bernardi, L. \& Mortelmans, D. (2018). Changing lone parents, changing life courses. In L.Bernardi \& D. Mortelmans (Eds.), Lone parenthood in the life course (pp. 126). Cham, Switzerland: Springer.

Brooks, C., Nieuwbeerta, P., \& Manza, J. (2006). Cleavage-Based Voting Behavior in Cross-National Perspective: Evidence From Six Postwar Democracies. Social Science Research, 35(1), 88-128.

Brown, E., Orbuch, T. L., \& Bauermeister, J. (2008). Religiosity and Marital Stability Among Black American and White American Couples. Family Relations, 57(2), $186-197$. 
Bröckel, M., \& Andreß, H.-J. (2015). The Economic Consequences of Divorce in Germany: What Has Changed Since the Turn of the Millennium? Comparative Population Studies, 40(3), 277-312.

Chapman, J. (1985). Marital Status, Sex and the Formation of Political Attitudes in Adult Life. Political Studies, 33(4), 592-609.

Coffé, H., \& Bolzendahl, C. (2010). Same Game, Different Rules? Gender Differences in Political Participation. Sex Roles, 62, 318-333.

Coffé, H., \& Need, A. (2010). Similarity in Husbands and Wives' Party Family Preference in the Netherlands. Electoral Studies, 29(2), 259-268.

Coleman, D. (2013). Partnership in Europe; its Variety, Trends and Dissolution. A Section of a Work in Progress. Finnish Yearbook of Population Research, (48), $5-49$.

Cooke, Lynn P. (2006). “Doing” Gender in Context: Household Bargaining and Risk of Divorce in Germany and the United States. American Journal of Sociology, 112(2), 442-472.

Davis, S. N., Greenstein, T. N., \& Marks, J. P. G. (2007). Effects of Union Type on Division of Household Labor. Journal of Family Issues, 28(9), 1246-1272.

De Graaf, P. M., \& Kalmijn, M. (2006). Change and Stability in the Social Determinants of Divorce: A Comparison of Marriage Cohorts in the Netherlands. European Sociological Review, 22(5), 561-572.

Duncan, G. J., \& Hoffman, S. D. (1985). A Reconsideration of the Economic Consequences of Marital Dissolution. Demography, 22(4), 485-497.

Edlund, L., Haider, L., \& Pande, R. (2005). Unmarried Parenthood and Redistributive Politics. Journal of the European Economic Association, 3(1), 95-119. 
Edlund, L., \& Pande, R. (2002). Why Have Women Become Left-Wing? The Political Gender Gap and the Decline in Marriage. The Quarterly Journal of Economics, 117(3), 917-961.

Evans, G. (2000). The Continued Significance of Class Voting. Annual Review of Political Science, 3(1), 401-417.

Fahs, B. (2007). Second Shifts and Political Awakenings. Journal of Divorce \& Remarriage, 47(3-4), 43-66.

Finseraas, H., Jakobsson, N., \& Kotsadam, A. (2012). The Gender Gap in Political Preferences: An Empirical Test of a Political Economy Explanation. Social Politics: International Studies in Gender, State \& Society, 19(2), 219-242.

Gerson, K. (1987). Emerging Social Divisions Among Women: Implications for Welfare State Politics. Politics \& Society, 15(2), 213-221.

González, L., \& Viitanen, T. K. (2009). The Effect of Divorce Laws on Divorce Rates in Europe. European Economic Review, 53(2), 127-138.

Greenstein, T.N. (1995). Gender Ideology, Marital Disruption, and the Employment of Married-Women. Journal of Marriage and the Family, 57(1), 31-42.

Haller, M., \& Hoellinger, F. (1994). Female Employment and the Change of Gender Roles: The Conflictual Relationship Between Participation and Attitudes in International Comparison. International Sociology, 9(1), 87-112.

Hohmann-Marriott, B. E. (2006), Shared Beliefs and the Union Stability of Married and Cohabiting Couples. Journal of Marriage and Family, 68, 1015-1028.

Inglehart, R., \& Norris, P. (2003). Rising Tide: Gender Equality and Cultural Change around the World. Cambridge: Cambridge University Press. 
Kalmijn, M., \& Broese van Groenou, M. (2005). Differential Effects of Divorce on Social Integration. Journal of Social and Personal Relationships, 22(4), 455476.

Kalmijn, M., De Graaf, P.M., \& Poortman, A.-R. (2004). Interactions Between Cultural and Economic Determinants of Divorce in the Netherlands. Journal of Marriage and Family, 66(1), 75-89.

Kalmijn, M., \& Poortman, A.-R. (2006). His or Her Divorce? The Gendered Nature of Divorce and its Determinants. European Sociological Review, 22(2), 201-214.

Kaufman, G. (2000). Do Gender Role Attitudes Matter? Family Formation and Dissolution Among Traditional and Egalitarian Women and Men. Journal of Family Issues, 21(1): 128-144.

Kennedy, S., \& Ruggles, S. (2014). Breaking Up Is Hard to Count: The Rise of Divorce in the United States, 1980-2010. Demography, 51(2), 587-598.

Kern, H. L. (2010). The Political Consequences of Transitions Out of Marriage in Great Britain. Electoral Studies, 29(2), 249-258.

Kingston, P. W., \& Finkel, S. E. (1987). Is There a Marriage Gap in politics? Journal of Marriage and the Family, 49(1), 57-64.

Kuhn, U. (2009). Stability and Change in Party Preference. Swiss Political Science Review, 15(3), 463-494.

Kuhn, U. (2016). Dynamics of Party Preferences: A Study on the Volatility and Stability of Individuals Using Household Panel Data from Germany, Great Britain and Switzerland. Universität Zürich: Zurich.

Lampard, R. J. (1997). Party Political Homogamy in Great Britain. European Sociological Review, 13(1), 79-99. 
Lehrer, E. L. (2004). Religion as a Determinant of Economic and Demographic Behavior in the United States. Population and Development Review, 30(4), 707726.

Leopold, T. (2018). Gender Differences in the Consequences of Divorce: A Study of Multiple Outcomes. Demography. Advance Online Publication. Doi: https://doi.org/10.1007/s13524-018-0667-6

Lipset, S. M. (1981). Political Man. Baltimore: Johns Hopkins University Press.

Lueptow, L.B., Guss, M.B., \& Hyden, C. (1989). Sex Role Ideology, Marital Status, and Happiness. Journal of Family Issues, 10, 383-400.

McGann, A.J., \& Kitschelt, H. (2005). The Radical Right in The Alps: Evolution of Support for the Swiss SVP and Austrian FPÖ. Party Politics, 11(2), 147-171.

Plissner, M. (1983). The Marriage Gap. Public Opinion, 5(4), 53.

Plutzer, E., \& McBurnett, M. (1991). Family Life and American Politics: The “Marriage Gap” Reconsidered. Public Opinion Quarterly, 55(1), 113-127.

Rehm, P. (2009). Risks and Redistribution. Comparative Political Studies, 42(7), 855881.

Ryser, V.-A. \& Le Goff, J.-M. (2015). Family attitudes and gender opinions of cohabiting and married mothers in Switzerland. Family Science, 6(1), 370-379).

Sanders, D. \& Brynin M. (1999) The Dynamics of Party Preference Change in Britain, 1991-1996. Political Studies, 47(2): 219-239.

Smith T.W. (2007). Changes in family structure, family values, and politics, 1972-2006. GSS Social Change Report 53, Chicago: National Opinion Research Center, University of Chicago.

Stoker, L., \& Jennings, M. K. (1995). Life-Cycle Transitions and Political Participation: The Case of Marriage. The American Political Science Review, 89(2), 421-433. 
Stoker, L., \& Jennings, M. K. (2005). Political Similarity and Influence between Husbands and Wives. In A. S. Zuckerman (Ed.), The Social Logic of Politics. Personal Networks as Contexts for Political Behavior (pp. 51-74). Philadelphia: Temple University Press.

Struffolino, E., \& Bernardi, L. (2016). Lone parents in Switzerland: Characteristics over time. Démos. Neuchatel: OFS.

Struffolino, E., Bernardi, L., \& Voorpostel, M. (2016). Self-reported Health among Lone Mothers in Switzerland: Do Employment and Education Matter? Population, 71(2), 187-213.

Thornton, A. (1985). Changing Attitudes Toward Separation and Divorce: Causes and Consequences. American Journal of Sociology, 90, 856-872.

Thornton, A. \& Freedman, D. (1979). Changes in the Sex Role Attitudes of Women, 1962-1977: Evidence From a Panel Study. American Sociological Review, 44, $831-842$.

Van der Brug, W., Hobolt, S. B., \& de Vreese, C. H. (2009). Religion and Party Choice in Europe. West European Politics, 32(6), 1266-1283.

Vaus D, Gray M, Qu L, et al. (2017) The economic consequences of divorce in six OECD countries. Australian Journal of Social Issues 52(2): 180-199.

Voorpostel, M., \& Coffé, H. (2012). Transitions in Partnership and Parental Status, Gender, and Political and Civic Participation. European Sociological Review, $28(1), 28-42$.

Weisberg, H. F. (1987). The Demographics of a New Voting Gap: Marital Differences in American Voting. Public Opinion Quarterly, 51(3), 335-343. 
Wilson, J. M., \& Lusztig, M. (2004). The Spouse in the House: What Explains the Marriage Gap in Canada? Canadian Journal of Political Science/Revue Canadienne de Science Politique, 37(4), 979-995.

Wrzus, C., Hänel, M., Wagner, J., \& Neyer, F. J. (2013). Social Network Changes and Life Events Across the Life Span: A Meta-Analysis. Psychological Bulletin, $139(1), 53-80$.

Zuckerman, A. S. (Ed.). (2005). The Social Logic of Politics. Personal Networks as Contexts for Political Behavior. Philadelphia, PA: Temple University Press.

Zuckerman, A. S., Fitzgerald, J., \& Dasović, J. (2005). Do Couples Support the Same Political Parties? Sometimes. Evidence from British and German Household Panel Surveys In A. S. Zuckerman (Ed.), The Social Logic of Politics. Personal Networks as Contexts for Political Behavior (pp. 75-94). Philadelphia: Temple University Press.

\section{Acknowledgements}

This study has been realized using the data collected by the Swiss Household Panel (SHP), which is based at FORS-the Swiss Centre of Expertise in the Social Sciences. The project is supported by the Swiss National Science Foundation. The authors are grateful to Sam Crawley and Anna Novis for their excellent editing work. 